\title{
PERCIVALL POTT'S DISEASE OF THE SPINE, DISCUSSED IN TWO LETTERS OF J. HUNCZOVSKY FROM LONDON, 1779, TO
}

\author{
G. A. BRAMBILLA IN VIENNA
}

Giovanni Alessandro Brambilla (1728-1800), ${ }^{1}$ to whom these two letters are addressed, was Body Surgeon (Leibchirurg) to the Emperor Joseph II (1741-90). His appointment in fact dates from 1764, the year before the widowed Empress Maria Teresa (1717-80) invited her young son, then the Archduke, to share the Imperial throne with her.

In 1778 Brambilla, trusted and esteemed by his sovereign, was appointed Chief Staff Surgeon (Oberstabschirurg) and in 1779 Sole Superintendent of the Army Health Service. Thus he, who had entered the Imperial Army as a simple Secondary Surgeon (Unterchirurg), was now in a position to realize his great dream of creating ex novo a surgical academy of university status. ${ }^{2} \mathrm{He}$ devoted particular care to the recruitment and training of the teaching faculty. For this purpose he selected certain young men of particular promise, awarded them grants for study abroad and placed them in the most outstanding teaching hospitals of other countries, above all in London and Paris.

The first of the instructors thus qualified was a Czech, Johann Hunczovsky (175298) 3 who, after about three years' study abroad, returned to Vienna towards the end of 1780 and published there in 1783 his Medicinisch-Chirurgische Beobachtungen auf seinen Reisen durch England und Frankreich, besonders ueber die Spitäler, illustrated with a portrait of Brambilla, to whom the work was dedicated.

One of the book's most substantial chapters-and one of the longest cerned with St. Bartholomew's Hospital in London which Hunczovsky had frequented in 1779, and where he came particularly under the influence of Percivall Pott (1714 88).

Twelve pages of the Beobachtungen ${ }^{5}$ are devoted to one of the diseases associated with Pott's name, as a result of his publishing in that very year 1779, in London, a monograph entitled Remarks on that Kind of Palsy of the Lower Limbs, which is frequently found to accompany a Curvature of the Spine, and is supposed to be caused by it. This 'nosological picture' is essentially formed by the association of two

1 W. Böcking, Rede bey der Todtenfeyer des Joh. Alexander, Reichsritters v. Brambilla, Vienna, 1801. C. A. Rigoni, Elogio del Cavaliere Gio. Alessandro Brambilla, Pavia, 1830. S. Kirchenberger, Kaiser Josef I. als Reformator des Osterr. Militär-Sanitäts-Wesens, Vienna, 1890. S. Kirchenberger, Lebensbilder hervorragender österreichisch-ungarischer Militär- und Marineärzte, Vienna and Leipzig, 1913, 16-20. L. Belloni, 'Lo strumentario di G. A. Brambilla, simbolo della "preminenza ed utilità" della chirurgia', Simposi clinici, 1971, 8, I-VIII. L. Belloni, Lo strumentario chirurgico di Giovanni Alessandro Brambilla al Museo di storia della scienza in Firenze ripristinato dai danni dell' alluvione del 4 Novembre 1966, Milan, 1971.

The Josephinum, an academy for the education of military surgeons, for the housing of which a worthy building was specially constructed in Währingerstrasse in Vienna, and inaugurated on 7 November 1785; this now houses the Institute of the History of Medicine of the University of Vienna.

J. A. Schmidt, Rede zum Andenken des k.k. Rathes und Professors Dr. J. N. Hunczovsky. Gehalten im Hörsale der k.k. medic. chirurg. Josephs-Akademie, als sie in voller Versammlung sein Todtengedächtniss feyerte, Vienna, 1798. S. Kirchenberger, Kais. Jos., 63-66; Lebensbilder, 78-81.

Pp. 4-40.

Sp. 20-31. 


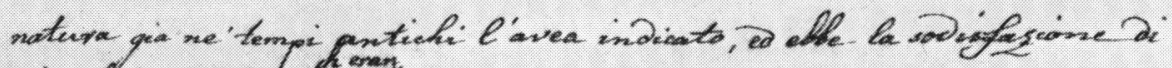

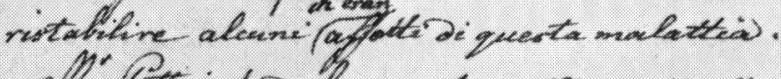

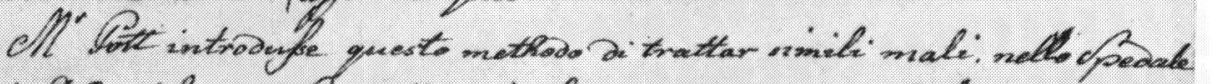

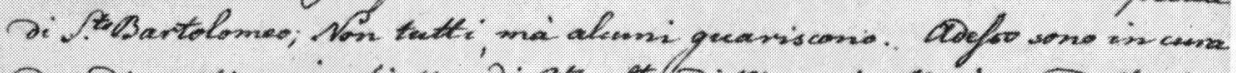

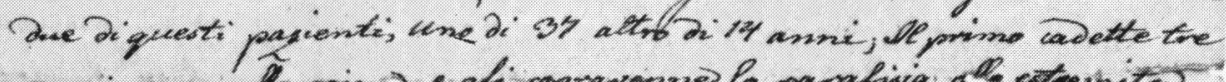

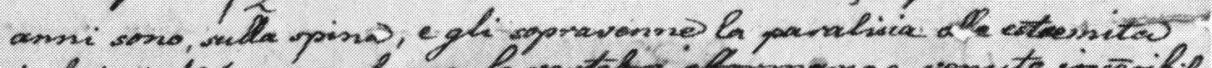

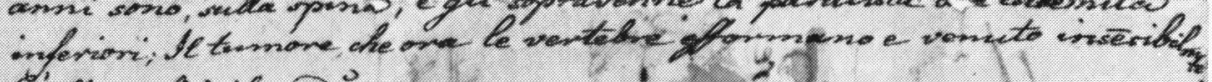
iblitro sofri il medemo accidente nella suck isfromsice. Calle Due maco hie qui giunte urrex poter meglio. che conte mix riserivens o'eferme, injicar i site: the il canterio fi applicats, esi prantiene-supposnente, nelfertino 20 sec settemane, - rill altor da ane mesi: ankitsare jtanne noreghis e privicyiatmente il nagagso comirccia a cemrisuar senzas estegrio.

C. C.ilChellomite Belgiosioss

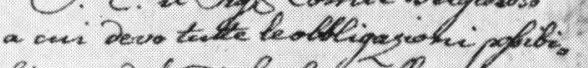
$=$ li, mi: jifse di famb linde cimpli:
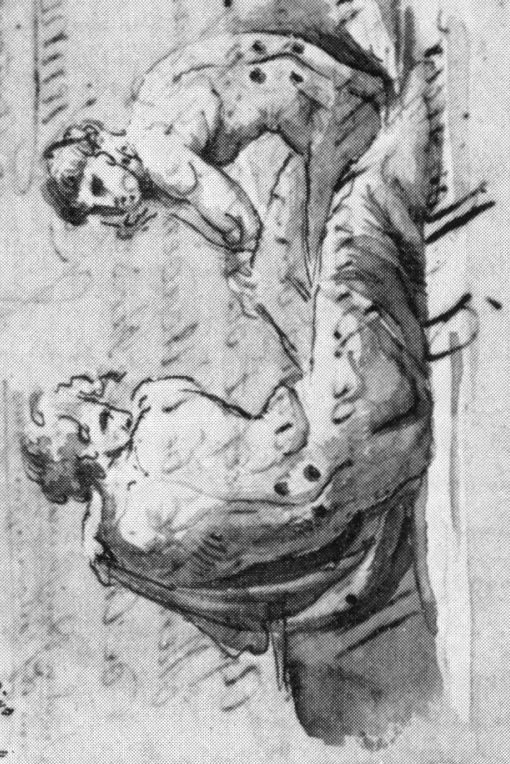

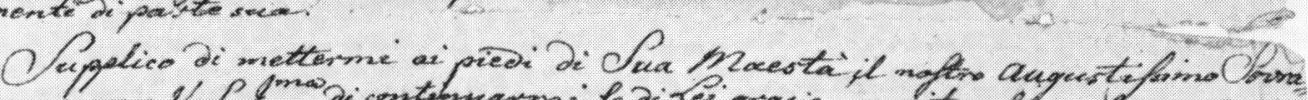

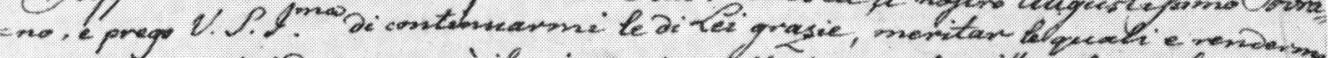

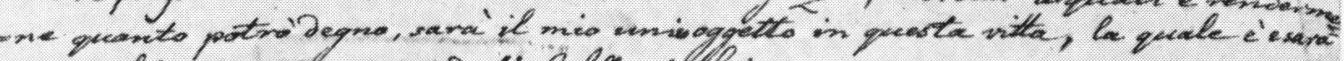

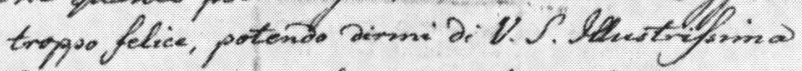

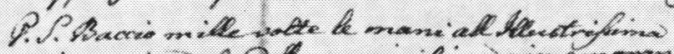

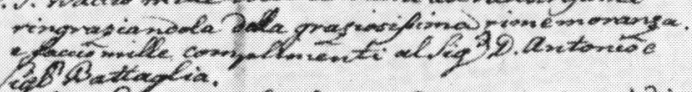

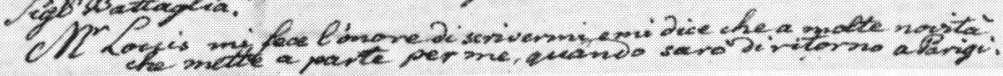

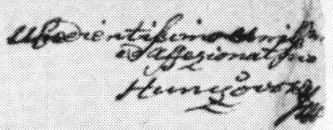




\section{Texts and Documents}

morbid phenomena-spastic paralysis of the lower limbs and curvature of the spine of non-traumatic origin (even if trauma may contribute to its appearance)-and it is further characterized by its reaction to therapy: mechanical aids applied to the curvature are ineffective, and even actually counterindicated. Some improvement, however, and even a cure may be obtained by opening fontanelles near the curvature, that is by a surgical intervention, since sanctioned by experience, which had been suggested by the favourable results observed in the case of spontaneous evacuation of pus from the same site. The nosological identification thus arrived at by Pott is fully 'worthy of Sydenham': ${ }^{6}$ Pott was also able to demonstrate the anatomicopathological basis of the disease, ${ }^{7}$ as clearly illustrated in the plates of his Farther Remarks on the useless State of the Lower Limbs, in consequence of a Curvature of the Spine (London, 1782).

Apart from the Beobachtungen mentioned above, Hunczovsky's observations and experiences during his long stay abroad are also recorded in the letters by which he kept Brambilla regularly informed: letters now preserved in the Biblioteca Civica of Pavia, the study of which forms the basis of this paper. Hunczovsky's letter from London, dated 11 June 1779, in particular contains information of special importance regarding Pott's clinical observations and therapeutic experiments. The third and last page of this letter is here reproduced ${ }^{8}$ (Plate 1) with an extract in Italian and English translation:

Il fuoco fù per così dire affatto bandito dalla prattica d' alcuni paesi da lungo tempo in quà; Si ricomincia ora a farne uso in alcuni mali, particolarmente delle ossa, qui come anche in Francia. Mr Pott va introducendone l' uso nelle curvature della spina che inducono la paralisia nelle estremità inferiori; Gia l' Ippocrate ci a lasciato un osservazione ch' un' simile paralisia fù guarita, dopo ch' un abscesso sopravenne al luogo della curvatur; Un Chirurgo nominato Jones in una delle provincie d' Inghilterra, dopo aver letta quest' osservazione, rissolse di produrr' col cauterio attuale una suppurazione, nel luogo, dove la natura gia ne' tempi antichi l' avea indicato, ed ebbe la sodisfazione di ristabilire alcuni ch' eran affetti di questa malattia.

Mr Pott introdusse questo methodo di trattar simili mali nello Spedale di Sto Bartolomeo; Non tutti, mà alcuni guariscono. Adesso sono in cura due di questi pazienti, Uno di 37 altro di 14 anni; Il primo cadette tre anni sono, sulla spina; e gli sopravenne la paralisia alle estremita inferiori; Il tumore, che ora le vertebre efformano e venuto insensibilmente. $L^{\prime}$ altro soffri il medesimo accidente nella sua infanzia.

Colle due macchie quì giunte vorrei poter meglio, che colla mia maniera d' esporre, indicar i siti, dove il cauterio fu applicato, e si mantiene suppurante, nel primo da sei settimane, e nell' altro da due mesi; Ambi le due stanno meglio e principalmente il ragazzo comincia a caminar senza sostegno.

'Though it may be said that cauterization was for a long time no longer practised in certain countries, it is now once again being employed here in England, as well as in France, for certain ailments, particularly those of the bone. Mr. Pott has started to use it for curvatures of the spine which cause paralysis of the lower limbs. Hippocrates has left us an observation that a similar paralysis was cured after an abscess

- This affirmation is made by the French translator of Farther remarks, Claude-François Duchanoy (1742-1827): Du mal vertébral ou de l'impotence des extrémités inférieures, qui reconnoît pour cause un vice de la Colonne Epinière; avec le moyen de la guérir, Paris, $1785, \mathrm{j}-\mathrm{ij}$.

' L. Belloni, 'Percivall Pott e il "morbo vertebrale di Pott"' (con radiogrammi di casi a lui attribuiti)', Simposi clinici, 1969, 6, XXV-XXXII. For other pathological bones of great historical significance preserved in the same hospital, see the note by the same author: 'Osteitis deformans 1876. Radiogrammi del primo caso di James Paget', ibid., 1967, 4, I-VIII.

Original dimensions 22.7 x $19.4 \mathrm{~cm}$. 
was formed on the site of curvature: a surgeon named Jones, in one of the provinces of England, having read this observation, resolved to produce suppuration by actual cauterization of the site already indicated by nature in ancient times, and had the satisfaction of curing some patients afflicted by this disease. ${ }^{9}$

'Mr. Pott introduced this method of treatment for similar ailments in St. Bartholomew's Hospital; not all, but some are cured. Two of these patients are being treated at the moment, one aged 37 , the other 14; the former fell on his spine three years ago and became paralysed in the lower limbs; the tumour which is now formed by the vertebrae developed imperceptibly. The latter suffered the same accident in infancy.

'The two sketches I enclose will, I hope, illustrate better than my manner of exposition the sites where cauterization was applied and suppuration continues, in the first case for six weeks, in the second for two months; both patients are improving and particularly the boy is starting to walk unaided.'

Hunczovsky returns to the same argument in his next letter, dated 2 August 1779:

Nella mia ultima ebbi l'ponore di notificar a V.a S.a Illustrissima la maniera, con cui Mr. Pott tratta i paralitici delle estremità inferiori, se il male à per cagione un tumore della spina dorsale; I due ch' eran allora in cura, sono quasi totalmente guariti andati in campagna.

'In my last letter I had the honour to inform your Excellency of Mr. Pott's method in treating paralysis of the lower limbs in cases where the ailment is caused by a tumour of the backbone. The two patients who were then undergoing treatment are now almost entirely cured and are [convalescing] in the country.'

It is no wonder, then, that one of the earliest mentions of the use of the fontanelles in what came to be called Pott's disease of the spine is to be found in Brambilla's Instrumentarium Chirurgicum. ${ }^{10}$

L. BELLONI

- See Pott's own account in Remarks, 22-23.

10 Instrumentarium chirurgicum Viennense, Vienna, 1780, 152: 'Die Engländer pflegen in der Lähmung der unteren Gliedmassen, seitwärts der Rückenwirbelbeine vier Fontanelle zu setzen, und haben vielen dadurch zur Genesung geholfen'. Instrumentarium chirurgicum militare Austriacum, Vienna, 1782, 155: 'Angli quoque in paralysi extremitates inferiores infestante fonticulos duos, tres, aut quatuor excitant ferro candente vertebris dorsalibus lateraliter adacto: quo methodo sanatos varios fuisse testantur.' 